\title{
Front Matter: Volume 7167
}

, "Front Matter: Volume 7167," Proc. SPIE 7167, Frontiers in Pathogen Detection: From Nanosensors to Systems, 716701 (11 March 2009); doi: 10.1117/12.827222

SPIE. Event: SPIE BiOS, 2009, San Jose, California, United States 


\section{PROGRESS IN BIOMEDICAL OPTICS AND IMAGING}

Vol. 10, No. 7

\section{Frontiers in Pathogen Detection: From Nanosensors to Systems}

Philippe M. Fauchet

Editor

24-26 January 2009

San Jose, California, United States

Sponsored and Published by

SPIE

Volume 7167

Proceedings of SPIE, 1605-7422, v. 7167

SPIE is an international society advancing an interdisciplinary approach to the science and application of light.

Frontiers in Pathogen Detection: From Nanosensors to Systems, edited by Philippe M. Fauchet,

Proc. of SPIE Vol. 7167, 716701 - (c) 2009 SPIE

CCC code: $1605-7422 / 09 / \$ 18 \cdot$ doi: $10.1117 / 12.827222$

Proc. of SPIE Vol. 7167 716701-1

Downloaded From: https://www.spiedigitallibrary.org/conference-proceedings-of-spie on 26 Apr 2023 Terms of Use: https://www.spiedigitallibrary.org/terms-of-use 
The papers included in this volume were part of the technical conference cited on the cover and title page. Papers were selected and subject to review by the editors and conference program committee. Some conference presentations may not be available for publication. The papers published in these proceedings reflect the work and thoughts of the authors and are published herein as submitted. The publisher is not responsible for the validity of the information or for any outcomes resulting from reliance thereon.

Please use the following format to cite material from this book:

Author(s), "Title of Paper," in Frontiers in Pathogen Detection: From Nanosensors to Systems, edited by Philippe M. Fauchet, Proceedings of SPIE Vol. 7167 (SPIE, Bellingham, WA, 2009) Article CID Number.

ISSN 1605-7422

ISBN 9780819474131

Published by

SPIE

P.O. Box 10, Bellingham, Washington 98227-0010 USA

Telephone +1 3606763290 (Pacific Time) · Fax +1 3606471445

SPIE.org

Copyright (C) 2009, Society of Photo-Optical Instrumentation Engineers.

Copying of material in this book for internal or personal use, or for the internal or personal use of specific clients, beyond the fair use provisions granted by the U.S. Copyright Law is authorized by SPIE subject to payment of copying fees. The Transactional Reporting Service base fee for this volume is $\$ 18.00$ per article (or portion thereof), which should be paid directly to the Copyright Clearance Center (CCC), 222 Rosewood Drive, Danvers, MA 01923. Payment may also be made electronically through CCC Online at copyright.com. Other copying for republication, resale, advertising or promotion, or any form of systematic or multiple reproduction of any material in this book is prohibited except with permission in writing from the publisher. The CCC fee code is 1605 $7422 / 09 / \$ 18.00$.

Printed in the United States of America.

Publication of record for individual papers is online in the SPIE Digital Library.

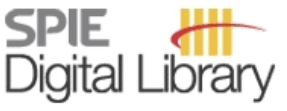

SPIEDigitalLibrary.org

Paper Numbering: Proceedings of SPIE follow an e-First publication model, with papers published first online and then in print and on CD-ROM. Papers are published as they are submitted and meet publication criteria. A unique, consistent, permanent citation identifier (CID) number is assigned to each article at the time of the first publication. Utilization of CIDs allows articles to be fully citable as soon they are published online, and connects the same identifier to all online, print, and electronic versions of the publication. SPIE uses a six-digit CID article numbering system in which:

- The first four digits correspond to the SPIE volume number.

- The last two digits indicate publication order within the volume using a Base 36 numbering system employing both numerals and letters. These two-number sets start with $00,01,02,03,04$, $05,06,07,08,09,0 A, 0 B \ldots$. OZ, followed by 10-1Z, 20-2Z, etc.

The CID number appears on each page of the manuscript. The complete citation is used on the first page, and an abbreviated version on subsequent pages. Numbers in the index correspond to the last two digits of the six-digit CID number. 


\section{Contents}

vii Conference Committee

SESSION 1 SYSTEMS

716702 Meeting current public health needs: optical biosensors for pathogen detection and analysis (Invited Paper) [7167-01]

M. Yang, University of Maryland, Baltimore County (United States); K. E. Sapsford, N. Sergeev, U.S. Food and Drug Administration (United States); S. Sun, University of Maryland, Baltimore County (United States); A. Rasooly, FDA (United States) and National Cancer Institute (United States)

716703 Low-cost, multiplexed biosensor for disease diagnosis (Invited Paper) [7167-02] C. J. Myatt, M. Delaney, K. Todorof, J. Heil, M. Givens, Precision Photonics Corp. (United States); R. T. Schooley, Division of Infectious Diseases, Univ. of California, San Diego (United States); M. J. Lochhead, Precision Photonics Corp. (United States)

716704 BioHawk portable pathogen detector (Invited Paper) [7167-03]

E. W. Saaski, Research International, Inc. (United States)

\section{SESSION 2 SPR AND SERS}

716705 Surface plasmon resonance biosensors for detection of foodborne pathogens and toxins (Invited Paper) [7167-04]

J. Homola, K. Hegnerová, M. Vala, Institute of Photonics and Electronics (Czech Republic)

716706 A microfluidic-based hybrid SPR/molecular imaging biosensor for the multiplexed detection of foodborne pathogens [7167-05]

M. D. Zordan, M. M. G. Grafton, G. Acharya, L. M. Reece, A. I. Aronson, K. Park, J. F. Leary, Purdue Univ. (United States)

\section{SESSION 3 MOSTLY WAVEGUIDES}

$71670 \mathrm{~A}$ Toward photostable multiplex analyte detection on a single mode planar optical waveguide [7167-09]

H. Mukundan, H. Xie, A. Anderson, W. K. Grace, J. S. Martinez, B. Swanson, Los Alamos

National Lab. (United States)

7167 OC Porous silicon waveguide with integrated grating coupler for DNA sensing [7167-11] X. Wei, C. Kang, G. Rong, Vanderbilt Univ. (United States); S. T. Retterer, Oak Ridge National Lab. (United States); S. M. Weiss, Vanderbilt Univ. (United States) 
7167 OD Multi-channel biodetection via resonant microcavities coupled to a photonic crystal waveguide [7167-12]

E. Guillermain, P. M. Fauchet, Univ. of Rochester (United States)

SESSION 4 POROUS AND PLANAR SILICON

7167 OF Design of a hybrid amine functionalized polyacrylamide hydrogel-porous silicon optical sensor [7167-14]

L. M. Bonanno, L. A. DeLouise, Univ. of Rochester (United States)

7167 OG Arrayed imaging reflectometry for inexpensive and label-free protein arrays (Invited Paper) [7167-15]

C. C. Striemer, Adarza BioSystems, Inc. (United States); C. R. Mace, Univ. of Rochester (United States); J. A. Carter, S. D. Mehta, Adarza BioSystems, Inc. (United States); B. L. Miller, Univ. of Rochester (United States)

$7167 \mathrm{OH}$ Tracking serum antibody response to viral antigens with arrayed imaging reflectometry [7167-16]

C. R. Mace, R. C. Rose, B. L. Miller, Univ. of Rochester (United States)

\section{SESSION 5 MOSTLY FLUIDICS I}

716701 A universal label-free biosensing plafform based on opto-fluidic ring resonators (Invited Paper) [7167-17]

H. Zhu, I. M. White, J. D. Suter, J. Gohring, X. Fan, Univ. of Missouri (United States)

7167 OJ Detection of E. coli O157:H7 in complex matrices under varying flow parameters with a robotic fluorometric assay system [7167-18]

S. D. Leskinen, S. M. Schlemmer, E. A. Kearns, D. V. Lim, Univ. of South Florida (United States)

7167 OK Controlled microfluidic interfaces for microsensors (Invited Paper) [7167-19]

H. Jiang, Univ. of Wisconsin, Madison (United States)

7167 OL Enhancing lab-on-a-chip performance via tunable parallel liquid mircolens arrays [7167-20]

Y. Liu, X. Zeng, L. Dong, H. Jiang, Univ. of Wisconsin, Madison (United States)

\section{SESSION 6 MOSTLY FLUIDICS II}

7167 ON Microflow cytometer [7167-22]

F. S. Ligler, J. S. Erickson, J. P. Golden, J. S. Kim, M. Nasir, P. J. Howell, A. L. Thangawng,

L. R. Hilliard, G. P. Anderson, Naval Research Lab. (United States)

716700 Sample preparation and assay refinements for pathogen detection platforms (Invited Paper) [7167-23]

D. V. Lim, E. A. Kearns, S. D. Leskinen, S. Magaña, J. M. Stroot, D. M. Hunter, S. M. Schlemmer, Univ. of South Florida (United States) 
$71670 Q \quad$ Robust sensing films for pathogen detection and medical diagnostics [7167-25]

A. S. Anderson, A. M. Dattelbaum, H. Mukundan, D. N. Price, W. K. Grace, B. I. Swanson, Los Alamos National Lab. (United States)

7167 OR DNA oligonucleotide synthesis in mesoporous silicon for biosensing applications [7167-26] J. L. Lawrie, Z. XU, P. E. Laibinis, Vanderbilt Univ. (United States); M. Molinari, Univ. of Reims Champagne (France); S. M. Weiss, Vanderbilt Univ. (United States)

7167 OS Detection of methicillin-resistant Staphylococcus aureus (MRSA) using the NanoLantern Biosensor (Invited Paper) [7167-27]

C. M. Strohsahl, B. L. Miller, Lighthouse Biosciences, LLC (United States) and Univ. of Rochester (United States); T. D. Krauss, Univ. of Rochester (United States)

7167 OT The role of alkanethiol spacers in a metal surface-based label-free DNA detection system [7167-28]

H.-I Peng, Z. M. Nuffer, B. L. Miller, Univ. of Rochester (United States)

\section{SESSION $8 \quad$ PLATFORMS AND APPLICATIONS}

7167 OV Detection of mitochondrial DNA with the compact bead array sensor system (CBASS) (Invited Paper) [7167-30]

S. P. Mulvaney, C. N. Ibe, Naval Research Lab. (United States); J. M. Caldwell, J. F. Levine, North Carolina State Univ. (United States); L. J. Whitman, Naval Research Lab. (United States) and NIST (United States); C. R. Tamanaha, Naval Research Lab. (United States)

$71670 \mathrm{X}$ Energy transfer-based biosensing of protease activity measured using an electroluminescent platform [7167-32]

K. E. Sapsford, U.S. Food and Drug Administration (United States); S. Sun, J. Francis, U.S. Food and Drug Administration (United States) and Univ. of Maryland, Baltimore County (United States); Y. Kostov, Univ. of Maryland, Baltimore County (United States); A. Rasooly, U.S. Food and Drug Administration (United States) and National Cancer Institute (United States);

D. Farrell, H. Mattoussi, I. L. Medintz, Naval Research Lab. (United States)

7167 OY Verifying of endocrine disruptor chemical affect to the mouse testes: Can Raman spectroscopy support histology study? [7167-33]

B. B. Andriana, The Institute of Physical and Chemical Research (RIKEN) (Japan) and The Univ. of Tokyo (Japan); Y. Oshima, S. Takanezawa, The Institute of Physical and Chemical Research (RIKEN) (Japan); T. W. Tay, C. L. Rosawati Soeratman, M. S. Alam, The Univ. of Tokyo (Japan); H. Mitsuoka, X. B. Zhu, T. Suzuki, Y. S. Yamamoto, N. Tsunekawa, The Institute of Physical and Chemical Research (RIKEN) (Japan); Y. Kanai, M. Kurohmaru, The Univ. of Tokyo (Japan); H. Sato, The Institute of Physical and Chemical Research (RIKEN) (Japan) 
C.-C. Wu, S. D. Alvarez, C. U. Rang, L. Chao, M. J. Sailor, Univ. of California, San Diego (United States)

Author Index

Proc. of SPIE Vol. 7167 716701-6

Downloaded From: https://www.spiedigitallibrary.org/conference-proceedings-of-spie on 26 Apr 2023 Terms of Use: https://www.spiedigitallibrary.org/terms-of-use 


\title{
Conference Committee
}

\author{
Symposium Chairs \\ James G. Fujimoto, Massachusetts Institute of Technology (United \\ States) \\ R. Rox Anderson, Wellman Center for Photomedicine, Massachusetts \\ General Hospital (United States) and Harvard Medical School \\ (United States)
}

Program Track Chair

Reza S. Malek, Mayo Clinic (United States)

Conference Chair

Philippe M. Fauchet, University of Rochester (United States)

Cochairs

Frances S. Ligler, Naval Research Laboratory (United States)

Benjamin L. Miller, University of Rochester (United States)

\section{Program Committee}

Carl A. Batt, Cornell University (United States)

Jeffrey L. Coffer, Texas Christian University (United States)

Harold Craighead, Cornell University (United States)

Jiri Homola, Czech Academy of Sciences (Czech Republic)

Hongrui Jiang, University of Wisconsin, Madison (United States)

Laura Maria Lechuga, Centro Nacional de Microelectrónica (Spain)

Deborah Leckband, University of Illinois at Urbana-Champaign (United States)

Sonia E. Letant, Lawrence Livermore National Laboratory (United States)

Daniel V. Lim, University of South Florida (United States)

Christopher J. Myatt, Precision Photonics Corporation (United States)

Michael J. Sailor, University of California, San Diego (United States)

Jerry Schultz, University of California at Riverside (United States)

Christopher C. Striemer, Pathologics (United States)

Christopher M. Strohsahl, Lighthouse Biosciences, LLC (United States)

Sharon M. Weiss, Vanderbilt University (United States) 


\author{
Session Chairs \\ 1 Systems \\ Philippe M. Fauchet, University of Rochester (United States) \\ 2 SPR and SERS \\ Frances S. Ligler, Naval Research Laboratory (United States) \\ 3 Mostly Waveguides \\ Michael J. Sailor, University of California, San Diego (United States) \\ 4 Porous and Planar Silicon \\ Sharon M. Weiss, Vanderbilt University (United States) \\ 5 Mostly Fluidics I \\ Benjamin L. Miller, University of Rochester (United States) \\ 6 Mostly Fluidics II \\ Laura Maria Lechuga, Centro d'Investigació en Nanociència i \\ Nanotecnologia (Spain) \\ $7 \quad$ Films and Substrates \\ Xudong Fan, University of Missouri, Columbia (United States) \\ 8 Platforms and Applications \\ Brian D. MacCraith, Dublin City University (Ireland)
}

